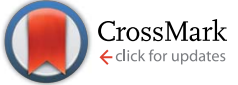

Cite this: Chem. Sci., 2017, 8, 3660

\title{
A bottom up approach towards artificial oxygenases by combining iron coordination complexes and peptides $\uparrow$
}

\begin{abstract}
Olaf Cussó, ${ }^{a}$ Michael W. Giuliano, ${ }^{b}$ Xavi Ribas, ${ }^{a}$ Scott J. Miller ${ }^{\star c}$ and Miquel Costas ${ }^{\star a}$
Supramolecular systems resulting from the combination of peptides and a chiral iron coordination complex catalyze asymmetric epoxidation with aqueous hydrogen peroxide, providing good to excellent yields and high enantioselectivities in short reaction times. The peptide is shown to play a dual role; the terminal carboxylic acid assists the iron center in the efficient $\mathrm{H}_{2} \mathrm{O}_{2}$ activation step, while its $\beta$-turn structure is crucial to induce high enantioselectivity in the oxygen delivering step. The high level of stereoselection $(84-92 \%$ ee) obtained by these supramolecular catalysts in the epoxidation of 1,1'-alkyl orthosubstituted styrenes, a notoriously challenging class of substrates for asymmetric catalysis, is not attainable with any other epoxidation methodology described so far. The current work, combining an iron center ligated to $\mathrm{N}$ and $\mathrm{O}$ based ligands, and a peptide scaffold that shapes the second coordination sphere, may be seen as a bottom up approach towards the design of artificial oxygenases.
\end{abstract}

Received 9th January 2017

DOI: $10.1039 / \mathrm{c} 7 \mathrm{sc00099e}$

rsc.li/chemical-science

transformations. ${ }^{\mathbf{8 - 1 2}}$ Traditional oxidants offer little selectivity in reactions of non-functionalized organic substrates, which remain, collectively, a great challenge in organic chemistry. Novel metallopeptide catalysts, by virtue of these discussed features, can offer effective solutions to this challenge. ${ }^{\mathbf{1 1}}$

Enzymatic oxidations catalyzed by iron oxygenases constitute paradigmatic examples of chemo-, regio- and stereoselective transformations that serve as inspiration for the design of iron oxidation catalysts (Scheme 1). Along this path, iron coordination complexes bearing nitrogen and oxygenbased ligands reproduce basic structural aspects of the first coordination sphere of the metal in non-heme oxygenases. Some of them have been shown to be capable of activating the $\mathrm{O}-\mathrm{O}$ bond in peroxides to form metal-based oxidants that perform selective $\mathrm{C}-\mathrm{H}$ and $\mathrm{C}=\mathrm{C}$ oxidation reactions. ${ }^{2,18}$ Highly enantioselective epoxidations, including those of notoriously difficult substrates have been recently described, but the current substrate scope remains narrow. ${ }^{19-26}$ A current limitation of this approach is the high sensitivity of the $\mathrm{H}_{2} \mathrm{O}_{2}$ distinctive chemo- and regioselective reactions. Furthermore, peptides are chiral and this confers metallopeptides with the potential ability of mediating stereoselective

${ }^{a}$ Institut de Química Computacional i Catàlisi (IQCC), Departament de Química, Universitat de Girona, Campus Montilivi, Girona E-17071, Catalonia, Spain. E-mail: miquel.costas@udg.edu

${ }^{b}$ Department of Chemistry and Biochemistry, College of Charleston, South Carolina, USA

${ }^{\circ}$ Department of Chemistry, Yale University, P.O. Box 208107, New Haven, Connecticut 06520-8107, USA. E-mail: scott.miller@yale.edu

$\dagger$ Electronic supplementary information (ESI) available: Experimental details of synthesis, characterization and NMR, HPLC and GC spectra. See DOI: 10.1039/c7sc00099e

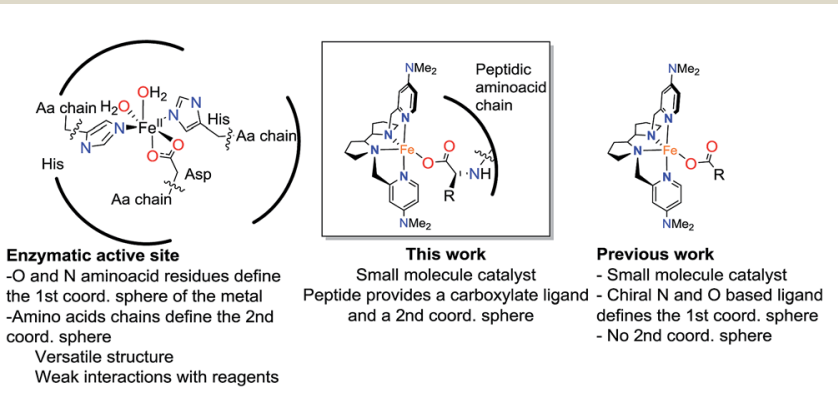

Scheme 1 
activation reaction to the catalyst structure. Unproductive consumption of $\mathrm{H}_{2} \mathrm{O}_{2}$, often accompanied by the generation of highly reactive radicals, is very commonly observed when modest changes are made in the first coordination sphere of the effective catalysts. ${ }^{27}$ The introduction of structural diversity in the second coordination sphere may represent a valuable alternative. In this regard, strategies that implement versatility while avoiding laborious ligand modifications will be particularly valuable. With these considerations in mind, herein we describe highly enantioselective supramolecular oxidation catalysts based on the combination of an iron coordination complex and a peptide. We illustrate the powerful reach of this approach in the highly enantioselective asymmetric epoxidation of $1,1^{\prime}$-alkyl substituted styrenes, a class of substrate that stands as a major problem for the asymmetric epoxidation systems described so far. ${ }^{28-31}$ Remarkably, high yield, and highly enantioselective epoxidation is accomplished in short reaction times (<30 min.) under mild experimental conditions using hydrogen peroxide as the oxidant with low catalyst loadings.

Precedents of this approach for developing selective oxidation catalysts are scarce. The combination of iron salts and peptide libraries with the aim to produce stereoselective epoxidations has been previously investigated by following a combinatorial approach. The optimized catalyst produced trans- $\beta$-styrene epoxide in up to $78 \%$ yield and up to $20 \%$ ee. ${ }^{32}$ On the other hand, peptides are chemically robust structures that withstand oxidation conditions and indeed they are organocatalysts for the asymmetric epoxidation (AE) of enones via a mechanism that involves the generation of basic hydrogen peroxide (Scheme 2a). ${ }^{33-36}$ More recently, key to the present work, Miller and co-workers have developed $\mathrm{a}_{2} \mathrm{O}_{2}$ activating relay in aspartate based peptide catalysts that enables the formation of peptide-based peracids ${ }^{\mathbf{3 7 - 4 0}}$ and dioxiranes, ${ }^{\mathbf{4 1}}$ which are mild electrophilic asymmetric epoxidation agents (Scheme $2 \mathrm{~b}$ and $\mathrm{c}$ ). It was envisioned that the incorporation of

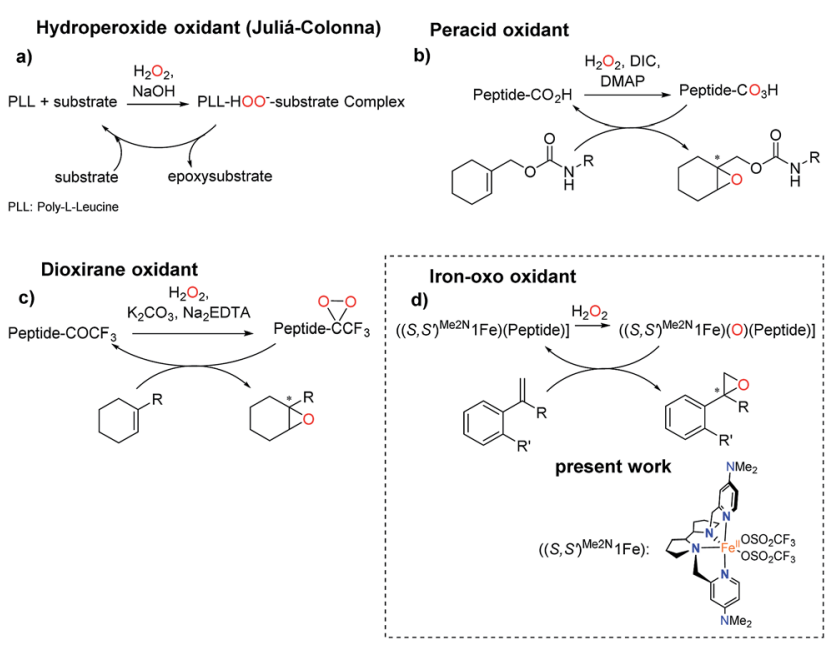

Scheme 2 Peptide-based catalysts for asymmetric epoxidation. (a) Hydroperoxide oxidant through the Juliá-Colonna process. ${ }^{36}$ (b) Peracid peptide oxidant for $A E .{ }^{37}$ (c) Dioxirane-peptide oxidant for $A E .{ }^{41}$ (d) Peptide for AE with an iron catalyst. an iron catalyst in these structures may allow the generation of high-valent iron-oxo intermediates, which are powerful oxidizing species, in a structurally rich and chiral environment that will imbue them with enhanced selectivity properties. Key to this approach are recent reports describing the synergistic cooperation of carboxylic acids and chiral iron catalysts in activating $\mathrm{H}_{2} \mathrm{O}_{2}$ to perform selective $\mathrm{C}-\mathrm{H}$ and $\mathrm{C}=\mathrm{C}$ oxidation reactions (Scheme $2 \mathrm{~d}){ }^{26}$

\section{Results and discussion}

\section{Catalyst development}

Our initial investigation of this approach entailed the epoxidation of $\boldsymbol{\alpha}$-methylstyrene S1, employing $\left(S, S^{\prime}\right)-\left[\mathrm{Fe}\left(\mathrm{CF}_{3} \mathrm{SO}_{3}\right)_{2}\left({ }^{\mathrm{Me} 2 \mathrm{~N}} \mathrm{pdp}\right)\right]$ $\left(\left(\boldsymbol{S}, \boldsymbol{S}^{\prime}\right)^{\mathbf{M e 2 N}} \mathbf{1 F e}\right)$ iron catalyst (Scheme 2d) and its analogous $\left(R, R^{\prime}\right)$ enantiomer ( $\left.2 \mathrm{~mol} \%\right)$, a peptide ( $\left.4 \mathrm{~mol} \%\right)$, (details on the preparation, and characterization of the peptides are collected in the ESI $\dagger$ ), and hydrogen peroxide as oxidant ( 2.3 equiv. added via syringe pump during $30 \mathrm{~min}$.) in acetonitrile solution at $0{ }^{\circ} \mathrm{C}$. Iron complex $\left(\boldsymbol{S}, \boldsymbol{S}^{\prime}\right)^{\mathbf{M e 2 N}} \mathbf{1 F e}$ was chosen because it has been recently shown to be particularly efficient in activating $\mathrm{H}_{2} \mathrm{O}_{2}$ requiring only catalytic amounts of carboxylic acid co-catalysts. $^{42}$ The terminal carboxylic acid of the peptide was envisioned to play this role in the current catalytic system. On the other hand, peptides chosen in the initial screening (see ESI $\dagger$ ) include peptides of different lengths, as well as peptides that may be biased toward secondary structures like $\beta$-turns. ${ }^{\mathbf{4 3 , 4 4}}$ Reactions were analyzed using chiral HPLC to determine conversions and stereoselectivities. The results were collected in the ESI Table $\mathrm{S} 1, \uparrow$ and results for representative examples of different peptides tested are shown in Scheme 3.

Reactions finished immediately after peroxide addition and product conversions ranged from $57 \%$ to $87 \%$, indicating that the system efficiently catalyzes the activation of $\mathrm{H}_{2} \mathrm{O}_{2}$ and epoxidizes the olefin with good chemoselectivity. Enantiomeric ratios range from a poor $52.5: 47.5$ (5\% ee) to a moderate $72.5: 27.5$ ( $45 \%$ ee), indicating that the peptide plays a major role in dictating the enantioselectivity of the reactions (See ESI, Table S1†). In all cases, for a given peptide, the chirality of the major epoxide enantiomer is dependent on the chirality of the metal complex; the $\left(S, S^{\prime}\right)^{\mathbf{M e 2 N}} \mathbf{1 F e}$ catalyst produces predominantly $S$-epoxide $(\boldsymbol{S})$-P1, while $(\boldsymbol{R})$-P1 is the main enantiomer of $\left(R, R^{\prime}\right)^{\mathbf{M e 2 N}} \mathbf{1 F e}$ catalyzed reactions. In general, for a given peptide, the enantioselectivity of $\mathbf{P 1}$ obtained when using $\left(S, S^{\prime}\right)^{\mathbf{M e 2 N}} \mathbf{1 F e}$ and $\left(R, R^{\prime}\right)^{\mathbf{M e 2 N}} \mathbf{1 F e}$ differs modestly $(<10 \%)$ but in specific cases differences in ee of $>25$ percentage units are observed (see peptide 2 in Scheme 3). Interestingly, a comparative analysis of the results obtained with this series of peptides shows that relatively large and possibly more flexible peptides 1-4 provide worse enantioselectivities (6-38\% ee) than the more rigid peptide 5 , which provides up to $45 \%$ ee, suggesting that the $\beta$-turn structure is key for this improvement.

The data also suggests that the relative position of the carboxylic acid moiety in the peptide also plays an important role in determining the stereoselectivity of the reactions. This is best exemplified by analyzing catalytic epoxidations under standard conditions using peptides 1-5. Pairs of peptides 1/2 

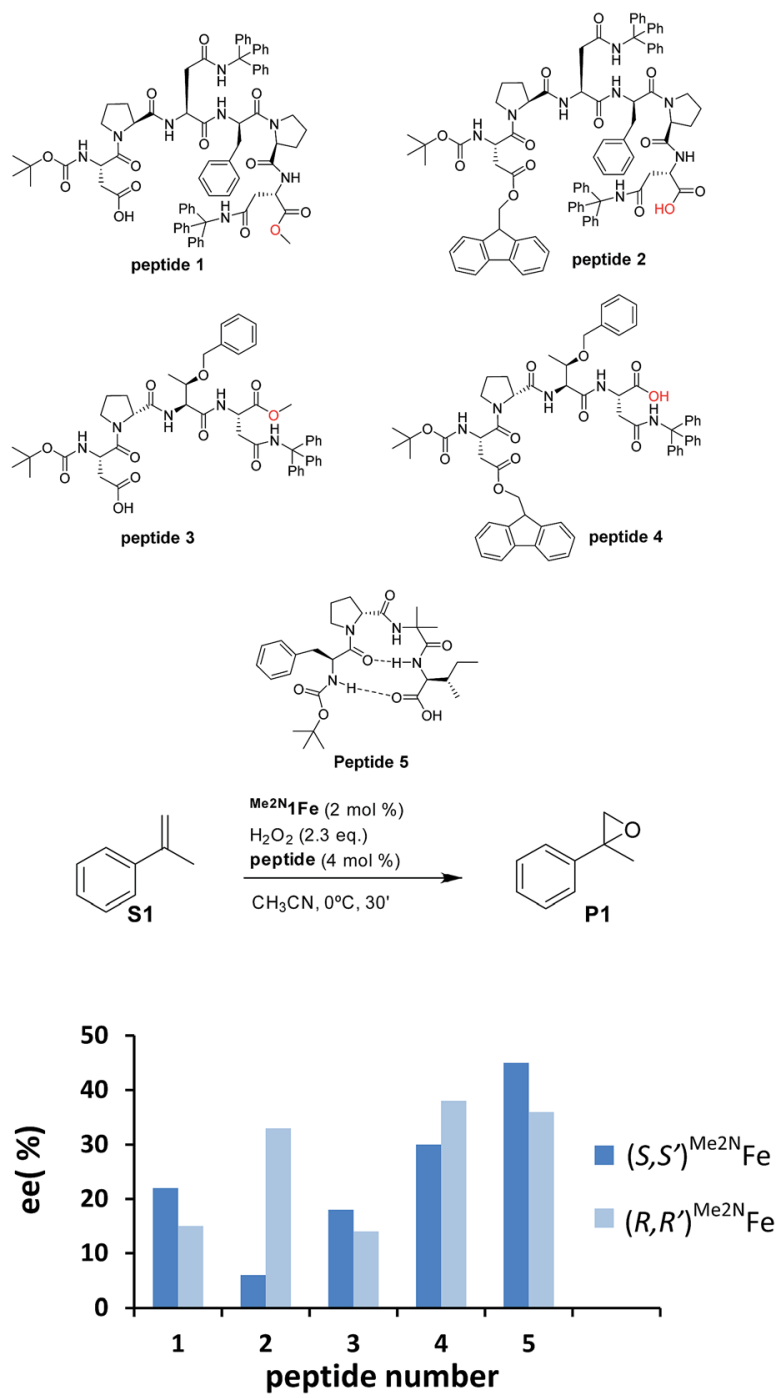

Scheme 3 (Top) Diagrams of five representative peptides studied (Bottom) Enantioselectivities produced in the asymmetric epoxidation of $\alpha$-methylstyrene (S1) with ${ }^{\mathrm{Me} 2 \mathrm{~N}} 1 \mathrm{Fe}$ and the corresponding peptide. Conditions: 2 mol\% of ${ }^{M e} 2 \mathrm{~N}_{1} \mathrm{Fe}, 2.3$ equiv. of $\mathrm{H}_{2} \mathrm{O}_{2}$, and $4 \mathrm{~mol} \%$ of peptide in acetonitrile at $0{ }^{\circ} \mathrm{C}$ for $30 \mathrm{~min}$. Dark blue bars show the results with enantiomer $S, S^{\prime}$ of the catalyst and light blue with enantiomer $R, R^{\prime}$ of the catalyst. ee's determined using HPLC.

and $3 / 4$ contain analogous peptide structures but differ in the position of the carboxylic acid moiety. Within each of the two pairs, we observed substantial differences in terms of enantioselectivity (Scheme 3). These are complex peptides and structure-activity correlations could not be easily deduced. Furthermore, some caution should be taken when making this comparison because this change may also impact on the overall structure and rigidity of the peptide. However, the comparison among the series of peptides suggests that the enantioselectivity of the oxygen atom transfer event depends on the chemical architecture of the region of the peptide in close proximity to the carboxylic acid moiety. The simplest interpretation of this data is that the carboxylic acid moiety acts as a ligand of the iron catalyst, thus resembling the role of simple alkyl carboxylic acids with this kind of iron catalyst. ${ }^{20 a, 42,45-49}$
Reasoning that the $\beta$-turn is a key structural element for stereoselectivity in the epoxidation reaction with ${ }^{\mathbf{M e 2 N}} \mathbf{1 F e}$, a set of peptides sharing this basic secondary structure but bearing diverse modifications were studied (Scheme 4). Interestingly, peptide 7, which contains a 4-hydroxyproline and is conformationally different than the peptides with the Aib residue $(\mathbf{5}, \mathbf{6}, \mathbf{8}, 9$ and 10), showed the best enantioselectivity, which was up to $58 \%$ ee when combined with $\left(S, S^{\prime}\right)^{\mathbf{M e 2 N}} \mathbf{1 F e}$. The combination of $\left(R, R^{\prime}\right)^{\mathbf{M e 2 N}} \mathbf{1 F e}$ with 7 resulted in a substantially lower ee (32\% ee), indicating an effective translation of the matching/
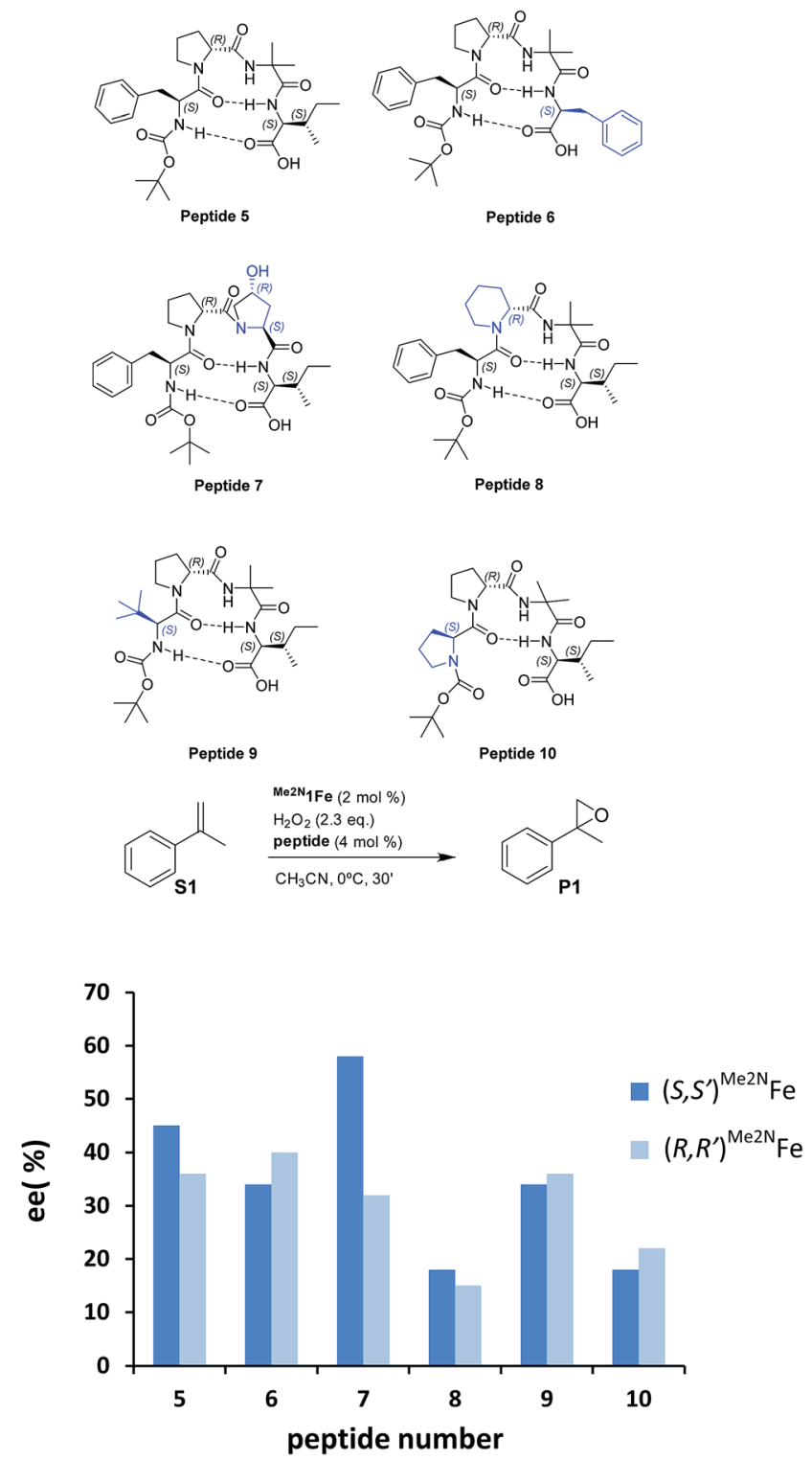

Scheme 4 (Top) Schematic diagrams of six different peptides derived from 5 (blue colored residues indicated sequence changes relative to peptide 5). (Bottom) Enantioselectivities for the asymmetric epoxidation of $\alpha$-methylstyrene with these peptides and ${ }^{\mathrm{Me} 2 \mathrm{~N}} 1 \mathrm{Fe}$. Conditions: 2 mol\% of $\mathrm{Me}^{2} \mathrm{~N}_{1} \mathrm{Fe}, 2.3$ equiv. of $\mathrm{H}_{2} \mathrm{O}_{2}$, and $4 \mathrm{~mol} \%$ of peptide in acetonitrile at $0{ }^{\circ} \mathrm{C}$ for 30 min. Dark blue bars show the results with enantiomer $S, S^{\prime}$ of the catalyst and light blue with enantiomer $R, R^{\prime}$ of the catalyst. ee's determined using HPLC. 
mismatching of the chirality of 7 and ${ }^{\mathbf{M e 2 N}} \mathbf{1 F e}$ in the enantioselectivity of the epoxidation. Also illustrative, we observed low enantioselectivities for peptide (10), which lacks the capacity to form a second hydrogen bond. Moreover the ${ }^{\mathrm{D}}$ proline group is also important because when it is replaced by ${ }^{\mathrm{D}}$ homoproline an erosion of enantioselectivity was observed (peptide 8). Also the modification of the first or last residue (peptides 6 and 9) showed worse enantioselectivities in comparison with peptide 5. In conclusion, this set of reactions led to the identification of 7 as the optimal peptide within the series. Furthermore, enantioselectivity may correlate with the presence of a peptide with a rigid, well-defined secondary structure.

\section{Characterization of the peptide-iron catalyst synergy}

Control experiments were performed in order to provide understanding into the role of the peptide and the iron complex in the $\mathrm{H}_{2} \mathrm{O}_{2}$ activation step (Table 1). Standard reaction conditions employed for comparison involved the use of catalyst Me2N 1 Fe (2 mol\%), peptide 7 ( $4 \mathrm{~mol} \%$ ) and $\mathrm{H}_{2} \mathrm{O}_{2}$ (2.3 equiv.) in acetonitrile at $0{ }^{\circ} \mathrm{C}$. Under these conditions, epoxide $(\boldsymbol{S})$-P1 is obtained in $81 \%$ yield and $58 \%$ ee (Table 1 , entry 1 ). Instead, in the absence of ${ }^{\mathbf{M e 2 N}} \mathbf{1 F e}$ no epoxide product was formed (Table 1, entry 2). This rules out the possibility that $\mathrm{H}_{2} \mathrm{O}_{2}$ is activated solely by the peptide, for example by formation of basic peroxide, or via generation of an organic peracid. Also the replacement of ${ }^{\mathbf{M e 2 N}} \mathbf{1 F e}$ by $\mathrm{Fe}(\mathrm{OTf})_{2}\left(\mathrm{CH}_{3} \mathrm{CN}\right)_{2}$ under standard reaction conditions did not produce epoxide product (Table 1 , entry 3). Most interestingly, the reaction in the absence of peptide 7 only showed epoxide traces (Table 1, entry 4). Therefore, both the peptide and the iron complex ${ }^{\mathbf{M e n}} \mathbf{1 F e}$ are necessary for efficient activation of $\mathrm{H}_{2} \mathrm{O}_{2}$. Enantioselectivity is not affected when equimolar ratios of ${ }^{\mathbf{M e 2}} \mathbf{1 F e}$ and peptide 7 are employed, but the use of a $2: 1$ ratio resulted in slightly decreased enantioselectivity (53\%). This set of observations strongly suggests that the active catalysts result from the equimolar combination of iron complex and peptide. As expected, the importance of the terminal carboxylic acid moiety of the peptide in the $\mathrm{H}_{2} \mathrm{O}_{2}$ activation was demonstrated, because low yield (12\%) and enantioselectivity (21\% ee) of epoxide P1 was observed when a terminal ester group was used in its place

Table 1 Epoxidation of $\alpha$-methylstyrene in different conditions ${ }^{a}$

\begin{tabular}{llllll}
\hline & & $\begin{array}{c}\text { Pept. 7 } \\
\text { Entry }\end{array}$ & Iron source $(2 \mathrm{~mol} \%)$ & \multicolumn{3}{c}{$\begin{array}{l}\text { Conv. } \\
(\mathrm{mol} \%)\end{array}$} & $\mathrm{H}_{2} \mathrm{O}_{2}$ (eq.) & $\begin{array}{l}\text { (yield) }(\%) \\
\text { ee (\%) }\end{array}$ \\
\hline 1 & $\left(\boldsymbol{S}, \boldsymbol{S}^{\prime}\right)^{\mathbf{M e 2 N}} \mathbf{1 F e}$ & 4 & 2.3 & $92(81)$ & 58 \\
2 & - & 4 & 2.3 & $-(-)$ & - \\
3 & $\mathrm{Fe}(\mathrm{OTf})_{2}\left(\mathrm{CH}_{3} \mathrm{CN}\right)_{2}$ & 4 & 2.3 & $-(-)$ & - \\
4 & $\left(\boldsymbol{S}, \boldsymbol{S}^{\prime}\right)^{\mathbf{M} 2 \mathbf{N}} \mathbf{1 F e}$ & - & 2.3 & Traces & $\mathrm{NA}^{b}$ \\
$5^{c}$ & $\left(\boldsymbol{S}, \boldsymbol{S}^{\prime}\right)^{\mathbf{M e 2 N}} \mathbf{1 F e}$ & 4 & 2.3 & $23(12)$ & 21
\end{tabular}

${ }^{a}$ Conditions: 2 mol\% of iron source, 2.3 equiv. of $\mathrm{H}_{2} \mathrm{O}_{2}$, and $4 \% \mathrm{~mol}$ of peptide in acetonitrile at $0{ }^{\circ} \mathrm{C}$ for $30 \mathrm{~min} .{ }^{b}$ Not available. ${ }^{c}$ The peptide contains a terminal ester instead of carboxylic acid (peptide 7-MeO, see ESI for peptide structure), also 5\% yield of acetophenone was observed. Substrate conversion, yields and ee's determined using HPLC.
(Table 1, entry 5). Furthermore, the observation of matching/ mismatching between the stereoisomer of the iron catalyst and peptide 7 with respect to reaction enantioselectivity strongly suggests an inner sphere interaction via the binding of the iron center by the peptide carboxylate. Characterization of these complexes is difficult because of their labile nature and because of the paramagnetic nature of the iron species. However, evidence in favor of their formation could be gathered using high resolution mass spectrometry (HRMS) under catalytic conditions. HRMS spectra collected during a catalytic epoxidation under standard conditions using a combination of $\left(\boldsymbol{S}, \boldsymbol{S}^{\prime}\right)^{\mathbf{M e 2 N}} \mathbf{1 F e}$ and 7 as catalyst show a dominant peak at $\mathrm{m} / \mathrm{z}=$ 1200.4962, that could be assigned to $\left\{\left(S, S^{\prime}\right)-\left[\mathrm{LFe}^{\mathrm{III}}\left(7^{\prime}\right)\right]\left(\mathrm{CF}_{3} \mathrm{SO}_{3}\right)\right\}^{+}$ species (where $7^{\prime}=7-\mathrm{H}^{+}$and $\mathrm{L}={ }^{\mathrm{MeN}}$ pdp) on the basis of their mass and isotopic pattern distribution. This species can be recognized as analogous to the carboxylate bound $\left\{\left(S, S^{\prime}\right)\right.$ $\left.\left[\mathrm{LFe}^{\mathrm{III}}(\mathrm{OAc})\right]\left(\mathrm{CF}_{3} \mathrm{SO}_{3}\right)\right\}^{+}$species, previously observed as the resting state in catalytic reactions with acetic acid. ${ }^{50}$ These species react with $\mathrm{H}_{2} \mathrm{O}_{2}$ producing the putative $\mathrm{Fe}^{\mathrm{V}}=\mathrm{O}$ species finally responsible for the oxygen atom transfer to the olefin. ${ }^{\mathbf{4 2}}$ Therefore, despite the fact that conclusive experimental evidence for carboxylate binding could not be obtained, the sum of the experimental observations led us to conclude that the catalytic activity should be attributed to $\left\{\left(S, S^{\prime}\right)\right.$ $\left.\left[\mathrm{LFe}^{\mathrm{III}}\left(7^{\prime}\right)\right]\left(\mathrm{CF}_{3} \mathrm{SO}_{3}\right)\right\}^{2+}$, in which the carboxylate moiety of the peptide presumably acts as a ligand. Therefore, we propose that this catalytic system reproduces key structural features of a number of non-heme iron dependent oxygenases; it contains a first coordination sphere that combines heterocyclic amines, carboxylate anions and labile sites, and the carboxylate group connects the metal center to an amino acid chain that participates in defining its second coordination sphere. ${ }^{51}$ The synergistic interplay of these elements is necessary to enable the efficient activation of $\mathrm{H}_{2} \mathrm{O}_{2}$ and the highly chemo- and enantioselective oxygen atom transfer.

The combination of $\left(\boldsymbol{S}, \boldsymbol{S}^{\prime}\right)^{\mathbf{M e 2 N}} \mathbf{1 F e}$ or $\left(\boldsymbol{R}, \boldsymbol{R}^{\prime}\right)^{\mathbf{M e 2 N}} \mathbf{1 F e}$ with the peptide will form different diastereoisomers, which a priori may exhibit different reactivities with $\mathrm{H}_{2} \mathrm{O}_{2}$, which in the current reaction is the rate determining step. Should this be the case, one of the diastereomers will dominate the outcome, resulting in non-linear effects on the overall enantioselectivity. In order to investigate this possibility, a study of the enantiomeric purity of the iron catalyst ${ }^{\mathbf{M e 2 N}} \mathbf{1 F e}$ as a function of enantioselectivity in the epoxidation of $\mathbf{S 4}$ was performed. When the reaction was performed with a racemic mixture of ${ }^{\mathbf{M e 2 N}} \mathbf{1 F e}$ and peptide 7 , the epoxide was obtained with only $10 \%$ ee (see ESI† for details), and a good linear correlation between the ee of the iron catalysts and the epoxide was observed (see ESI Fig. SI. $2 \dagger$ ) discarding the presence of non-linear effects. This analysis indicates that the activation of $\mathrm{H}_{2} \mathrm{O}_{2}$ by $\left(\boldsymbol{S}, \boldsymbol{S}^{\prime}\right)^{\mathbf{M e 2 N}} \mathbf{1 F e}$ and 7 , or $\left(\boldsymbol{R}, \boldsymbol{R}^{\prime}\right)^{\mathbf{M e 2 N}} \mathbf{1 F e}$ and 7 occurs at indistinguishable rates, but the stereoselectivity of the oxygen atom transfer event is different.

\section{Substrate scope}

With the optimal peptide in hand, the asymmetric epoxidation of different $\alpha$-methylstyrene derivatives was studied. Reactions 
were performed at $-30{ }^{\circ} \mathrm{C}$, in order to obtain improved enantioselectivities (Table 2). For meta-, para- and non-substituted derivatives (S1-S3), the enantioselectivities obtained were moderate, from $64 \%$ to $68 \%$ (Table 2 , entry $1-3$ ). But in the case of the ortho-methyl substituted styrene derivative (S4) the enantioselectivity increased up to $92 \%$ (Table 2 , entry 4 ). The ability of peptide 7 is exclusive in order to provide high enantioselectivity in the epoxidation of ortho-susbtituted $\alpha$-methylstyrene substrates. This is best illustrated when reactions were performed using carboxylic acid co-ligands previously described in asymmetric iron catalyzed oxidations; these included acetic acid, 2-ethylhexanoic acid, $S$-ibuprofen and Npha-Ileu-OH (see Fig. 1). The last three acids were identified in previous works as the best partners for ${ }^{\mathbf{M} 2 \mathbf{N}} \mathbf{1 F e}$ in the asymmetric epoxidation of a wide range of substrates, including $\alpha$-methylstyrene substrates. $^{\mathbf{4 2 , 4 5}}$ In all cases, the ee's were substantially lower than those obtained with peptide 7 in the AE of S4. For example the best result at $0{ }^{\circ} \mathrm{C}$ was obtained with $S$-ibuprofen and $\left(\boldsymbol{S}, \boldsymbol{S}^{\prime}\right)^{\mathbf{M e 2 N}} \mathbf{1 F e}$, providing the corresponding epoxide with $68 \%$ ee that improved up to $78 \%$ ee at $-30{ }^{\circ} \mathrm{C}$. Under analogous conditions $\left(0{ }^{\circ} \mathrm{C}\right)$, peptide 7 combined with $\left(\boldsymbol{S}, \boldsymbol{S}^{\prime}\right)^{\mathbf{M e 2 N}} \mathbf{1 F e}$ provided a remarkable $81 \%$ ee, which improved up to $92 \%$ ee at $-30{ }^{\circ} \mathrm{C}$. The electron rich catalyst $\left(\boldsymbol{S}, \boldsymbol{S}^{\prime}\right)^{\mathbf{M e 2 N}} \mathbf{1 F e}$ appears to be crucial in terms of yield and enantioselectivity; when $\left(S, S^{\prime}\right)$ and $\left(R, R^{\prime}\right)-\left[\mathrm{Fe}\left(\mathrm{CF}_{3} \mathrm{SO}_{3}\right)_{2}(\mathrm{pdp})\right]$ were employed instead of

Table 2 Asymmetric epoxidation of different $\alpha$-methylstyrene derivatives with $\left(S, S^{\prime}\right)^{\mathrm{Me} 2 \mathrm{~N}} 1 \mathrm{Fe}, \mathrm{H}_{2} \mathrm{O}_{2}$ and peptide $7^{a}$

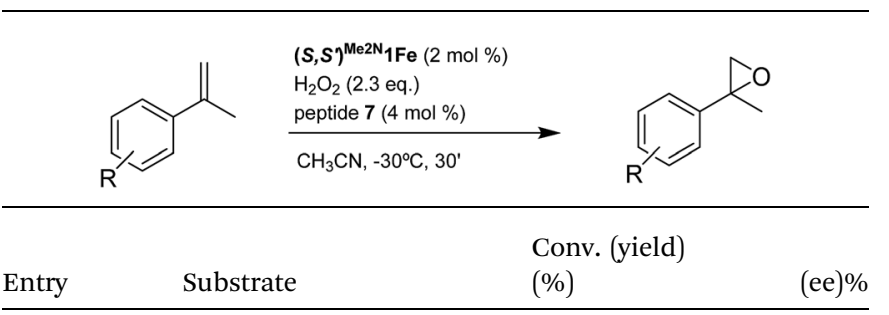

1<smiles>C=C(C)c1ccccc1</smiles>

(S1)

2<smiles>C=C(C)c1ccc(F)cc1</smiles>

(S2)

3<smiles>C=C(C)c1cccc(C(F)(F)F)c1</smiles>

(S3)
$94(80)$

$99(81)$

$75^{b}$

$80^{b}$
64

66

68

92
${ }^{a}$ Unless stated, reaction conditions are $2 \mathrm{~mol} \%$ of $\left(\boldsymbol{S}, \boldsymbol{S}^{\prime}\right)^{\mathbf{M e 2 N}} \mathbf{1 F e}, \mathrm{H}_{2} \mathrm{O}_{2}$ (2.3 equiv.) and peptide $7(4 \mathrm{~mol} \%)$ in $\mathrm{CH}_{3} \mathrm{CN}$ at $-30{ }^{\circ} \mathrm{C}$ for $30 \mathrm{~min}$. ${ }^{5}$ Isolated yields. ee's determined using chiral GC and HPLC.

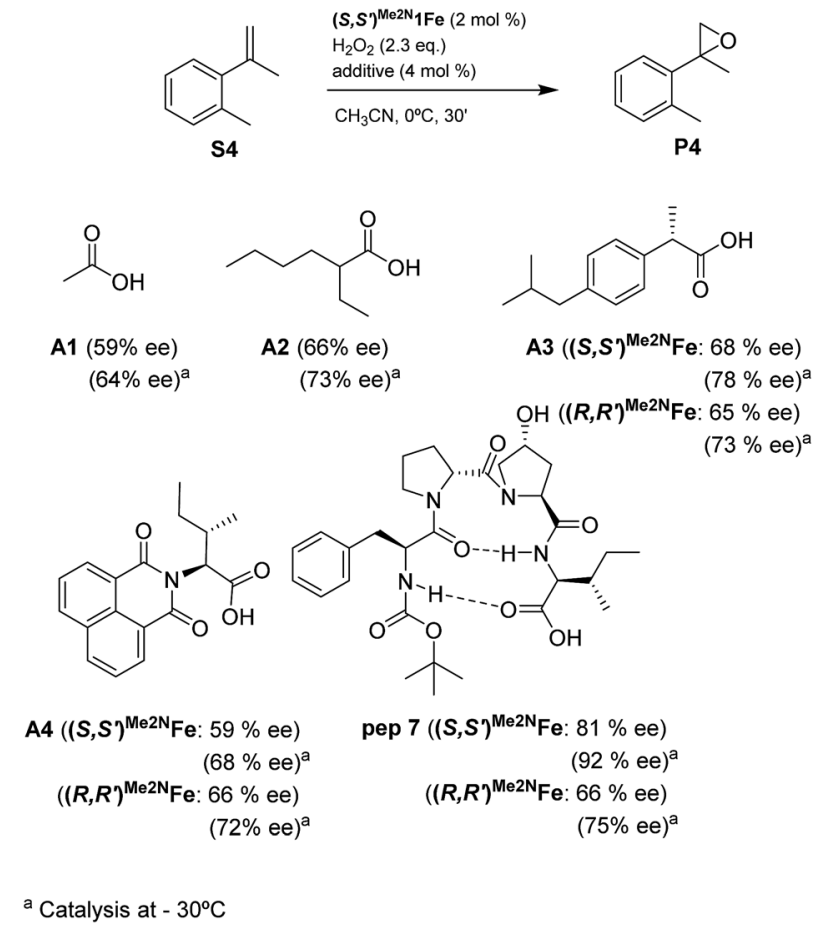

Fig. 1 Structures of different carboxylic acids and the enantioselectivities obtained with both enantiomers of ${ }^{\mathrm{Me} 2 \mathrm{~N}} 1 \mathrm{Fe}$ in the catalytic epoxidation of S4. Conditions: 2 mol\% of catalyst, 2.3 equiv. of $\mathrm{H}_{2} \mathrm{O}_{2}$, and $4 \% \mathrm{~mol}$ of peptide in acetonitrile at $0{ }^{\circ} \mathrm{C}$ and $-30{ }^{\circ} \mathrm{C}$ for $30 \mathrm{~min}$.

$\left(\boldsymbol{S}, \boldsymbol{S}^{\prime}\right)^{\mathbf{M e 2 N}} \mathbf{1 F e}$, the epoxidation of $\mathbf{S} 4$ proceeds with low yields and enantioselectivities ( $7 \%$ yield (31\% ee) and $16 \%$ yield ( $9 \%$ ee), respectively).

A series of ortho-substituted $\alpha$-methylstyrene derivatives were tested in the asymmetric epoxidation reaction (Table 3). We observed good tolerance of the system to the introduction of different halogen groups $(\mathrm{Cl}, \mathrm{F}$ and $\mathrm{Br})$ in the ortho position, showing in all cases good to excellent yields and enantioselectivities, up to $82 \%$ and $90 \%$, respectively (Table 3, entries 1$3)$. In the case of the nitro derivative $\mathbf{S 1 0}$, with a $\mathrm{NO}_{2}$ group in the meta-position, excellent yield and very good enantioselectivity, 99\% yield and $86 \%$ ee (entry 6) were obtained. Finally, this methodology showed excellent enantioselectivities for cisaromatic olefins (S11 and S12), which to the best of our knowledge are the best reported so far with iron catalysts, up to 91\% ee (entry 7 and 8).

These results must be placed into context. $\alpha$-Alkyl substituted styrenes are recognized as particularly challenging substrates for asymmetric catalysis. ${ }^{52}$ Furthermore, for the specific case of ortho-substituted $\alpha$-methylstyrene derivatives there are no epoxidation systems in the literature describing high stereoselectivities, and enantioenriched products could only be obtained via the hydrolytic kinetic resolution of orthosubstituted styrene epoxide derivatives. ${ }^{53}$ Therefore, the current catalysts can be regarded as a promising platform for the identification of peptides to improve the enantioselectivity of $\mathrm{Fe}$ catalysts. 
Table 3 Substrate scope of ortho-substituted $\alpha$-1,1-disubstituted styrene derivatives in the asymmetric epoxidation reaction with $\left(S, S^{\prime}\right)^{\text {Me2N }} 1 \mathrm{Fe}$ as catalyst and peptide $7^{a}$

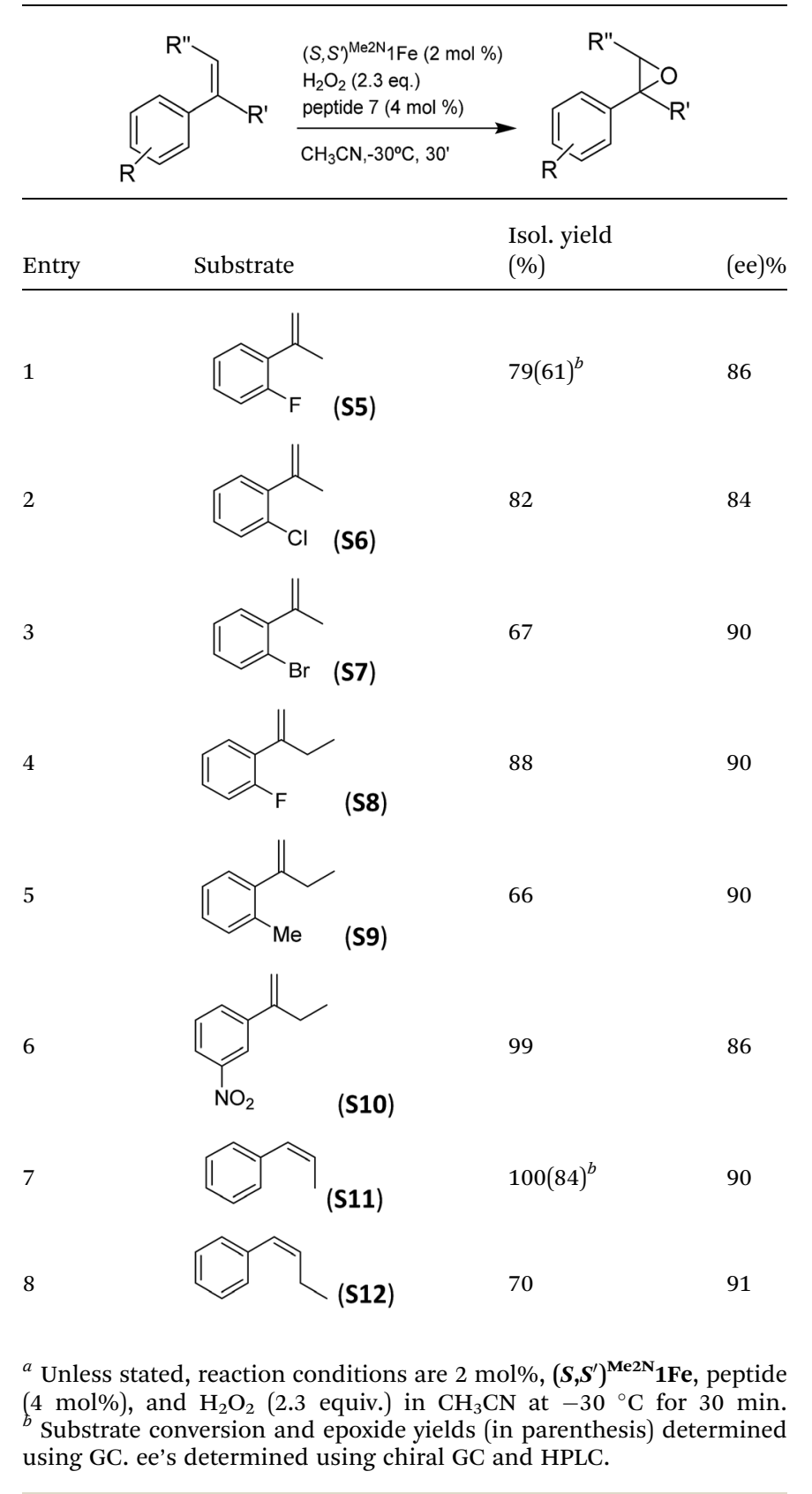

\section{Conclusions}

This work describes a supramolecular system based on the combination of a chiral iron coordination complex and a peptide with a $\beta$-turn design that activates $\mathrm{H}_{2} \mathrm{O}_{2}$ and performs high enantioselective epoxidation of $\alpha$-alkyl-substituted and cissubstituted styrene derivatives. Reactions are performed in short reaction times, employing aqueous hydrogen peroxide as oxidant, and ee's are remarkably high for substrates that are recognized as particularly difficult, and which lack satisfactory alternatives. The carboxylic acid moiety of the peptide is shown to help the iron center in the activation of the $\mathrm{H}_{2} \mathrm{O}_{2}$ while the rigid well-defined $3 \mathrm{D}$ architecture of the peptide appears to be crucial for eliciting high enantioselectivities. This combination of an iron center ligated to $\mathrm{N}$ and $\mathrm{O}$ based ligands, and a peptide scaffold that contributes to shaping the second coordination sphere may be seen as a bottom up approach towards the design of artificial peroxigenases. Furthermore, this approach is envisioned to have a powerful reach. Multiple catalytic systems could be envisioned, based on the chemical versatility of peptides, without the need to manipulate the iron catalyst. The current system appears to rely on the structural architecture of the peptide and operates on non-functionalized olefins. The rich functional group versatility of the peptides may serve to introduce residues with additional properties such as charge, $\mathrm{H}$ bonding, and hydrophobic interactions, among others. These interactions are presently employed in highly enantioselective organocatalysis, and may boost the substrate scope and overall performance of the current catalytic system.

\section{Acknowledgements}

MC acknowledge financial support from MINECO of Spain and Fondo Europeo de Desarrollo Regional (CTQ2015-70795-P/ $\mathrm{BQU})$, and the Catalan Department for Innovation, Universities and Enterprise (DIUE) of the Generalitat de Catalunya (2009SGR637). SJM is grateful to the NIGMS of the NIH for support (GM-096403). M. C. and X. R. thank ICREA-Acadèmia awards. We thank STR's from UdG for technical support.

\section{Notes and references}

1 R. H. Holm, P. Kennepohl and E. I. Solomon, Chem. Rev., 1996, 96, 2239.

2 L. Que Jr and W. B. Tolman, Nature, 2008, 455, 8.

3 S. Sahu and D. P. Goldberg, J. Am. Chem. Soc., 2016, 138, 11410.

4 X. Engelmann, I. Monte-Pérez and K. Ray, Angew. Chem., Int. Ed., 2016, 55, 7632.

5 K. Ray, F. F. Pfaff, B. Wang and W. Nam, J. Am. Chem. Soc., 2014, 136, 13942.

6 Y. Lu, N. Yeung, N. Sieracki and N. M. Marshall, Nature, 2009, 460, 855.

7 T. Heinisch and T. R. Ward, Curr. Opin. Chem. Biol., 2010, 14, 184.

8 R. Sambasivan and Z. T. Ball, J. Am. Chem. Soc., 2010, 132, 9289.

9 R. Sambasivan and Z. T. Ball, Angew. Chem., Int. Ed., 2012, 51, 8568.

10 N. S. Josephsohn, K. W. Kuntz, M. L. Snapper and A. H. Hoveyda, J. Am. Chem. Soc., 2001, 123, 11594.

11 S. R. Gilbertson, S. E. Collibee and A. Agarkov, J. Am. Chem. Soc., 2000, 122, 6522.

12 B. Kim, A. J. Chinn, D. R. Fandrick, C. H. Senanayake, R. A. Singer and S. J. Miller, J. Am. Chem. Soc., 2016, 138, 7939.

13 J. C. Lewis, ACS Catal., 2013, 3, 2954.

14 J. Bos and G. Roelfes, Curr. Opin. Chem. Biol., 2014, 19, 135. 
15 J. C. Lewis, Curr. Opin. Chem. Biol., 2015, 25, 27.

16 W. J. Shaw, Catal. Rev.: Sci. Eng., 2012, 54, 489.

17 P. J. Deuss, R. den Heeten, W. Laan and P. C. Kamer, Chem.Eur. J., 2011, 17, 4680.

18 W. N. Oloo and L. Que, Acc. Chem. Res., 2015, 48, 2612.

19 A. Fingerhut, O. V. Serdyuk and S. B. Tsogoeva, Green Chem., 2015, 17, 2042.

20 For selected examples of Fe-catalyzed epoxidation reactions see: (a) M. C. White, A. G. Doyle and E. N. Jacobsen, J. Am. Chem. Soc., 2001, 123, 7194; (b) G. Dubois, A. Murphy and T. D. P. Stack, Org. Lett., 2003, 5, 2469; (c) G. Anilkumar, B. Bitterlich, F. G. Gelalcha, M. K. Tse and M. Beller, Chem. Commun., 2007, 3, 289; (d) P. Liu, E. L. Wong, A. W. Yuen and C. Che, Org. Lett., 2008, 10, 3275; (e) K. Schröder, S. Enthaler, B. Join, K. Junge and M. Beller, Adv. Synth. Catal., 2010, 352, 1771; (f) K. Schroeder, S. Enthaler, B. Bitterlich, T. Schulz, A. Spannenberg, M. K. Tse, K. Junge and M. Beller, Chem.-Eur. J., 2009, 15, 5471; (g) K. Schröder, B. Join, A. J. Amali, K. Junge, X. Ribas, M. Costas and M. Beller, Angew. Chem., Int. Ed., 2011, 50, 1425; (h) E. A. Mikhalyova, O. V. Makhlynets, T. D. Palluccio, A. S. Filatov and E. V. Rybak-Akimova, Chem. Commun., 2012, 48, 687; (i) B. F. Perandones, E. D. Nieto, C. Godard, S. Castillon, P. De Frutos and C. Claver, ChemCatChem, 2013, 5, 1092; (j) I. Y. Skobelev, E. V. Kudrik, O. V. Zalomaeva, F. Albrieux, P. Afanasiev, O. A. Kholdeeva and A. B. Sorokin, Chem. Commun., 2013, 49, 5577; $(k)$ D. Clemente-Tejeda, A. López-Moreno and F. A. Bermejo, Tetrahedron, 2013, 69, 2977; (l) J. W. Kuck, A. Raba, I. I. E. Markovits, M. Cokoja and F. E. Kuhn, ChemCatChem, 2014, 6, 1882-1886.

$21 \mathrm{Fe}$ systems showing moderate stereoselectivity: (a) C. Marchi-Delapierre, A. Jorge-Robin, A. Thibon and S. Ménage, Chem. Commun., 2007, 11, 1166; (b) H.-L. Yeung, K.-C. Sham, C.-S. Tsang, T.-C. Lau and H.-L. Kwong, Chem. Commun., 2008, 3801; (c) F. Oddon, E. Girgenti, C. Lebrun, C. Marchi-Delapierre, J. Pecaut and S. Menage, Eur. J. Inorg. Chem., 2012, 85.

22 (a) B. Wang, S. Wang, C. Xia and W. Sun, Chem.-Eur. J., 2012, 18, 7332; (b) M. Wu, C.-X. Miao, S. Wang, X. Hu, C. Xia, F. E. Kühn and W. Sun, Adv. Synth. Catal., 2011, 353, 3014; (c) O. Y. Lyakin, R. V. Ottenbacher, K. P. Bryliakov and E. P. Talsi, ACS Catal., 2012, 2, 1196; (d) Q. F. Cheng, X. Y. Xu, W. X. Ma, S. J. Yang and T. P. You, Chin. Chem. Lett., 2005, 16, 1467; (e) W. Dai, G. Li, B. Chen, L. Wang and S. Gao, Org. Lett., 2015, 17, 904; (f) F. G. Gelalcha, G. Anilkumar, M. K. Tse, A. Brückner and M. Beller, Chem.-Eur. J., 2008, 14, 7687; (g) F. G. Gelalcha, B. Bitterlich, G. Anilkumar, M. K. Tse and M. Beller, Angew. Chem., Int. Ed., 2007, 46, 7293.

$23 \mathrm{Fe}$ systems that employ hypervalent iodine oxidants: (a) T. Niwa and M. Nakada, J. Am. Chem. Soc., 2012, 134, 13538; (b) B. Wang, Y.-M. Lee, M. S. Seo and W. Nam, Angew. Chem., Int. Ed., 2015, 54, 11740.

24 L. Luo and H. Yamamoto, Eur. J. Org. Chem., 2014, 35, 7803. 25 Y. Nishikawa and H. Yamamoto, J. Am. Chem. Soc., 2011, 133, 8432.
26 O. Cusso, X. Ribas and M. Costas, Chem. Commun., 2015, 51, 14285.

27 K. Chen, M. Costas, J. Kim, A. K. Tipton and L. Que Jr, J. Am. Chem. Soc., 2002, 124, 3026.

28 G. De Faveri, G. Ilyashenko and M. Watkinson, Chem. Soc. Rev., 2011, 40, 1722.

29 Y. Zhu, Q. Wang, R. G. Cornwall and Y. Shi, Chem. Rev., 2014, 114, 8199.

30 R. L. Davis, J. Stiller, T. Naicker, H. Jiang and K. A. Jørgensen, Angew. Chem., Int. Ed., 2014, 53, 7406.

31 C. Wang and H. Yamamoto, Chem.-Asian J., 2015, 10, 2056.

32 M. B. Francis and E. N. Jacobsen, Angew. Chem., Int. Ed., 1999, 38, 937.

33 G. Carrea, S. Colonna, A. D. Meek, G. Ottolina and S. M. Roberts, Chem. Commun., 2004, 1412.

34 E. Weitz and A. Scheffer, Ber. Dtsch. Chem. Ges., 1921, 54, 2327.

35 Y. Apeloig, M. Karni and Z. Rapoport, J. Am. Chem. Soc., 1983, 105, 2784.

36 S. Julia, J. Masana and J. C. Vega, Angew. Chem., Int. Ed., 1980, 19, 929.

37 G. Peris, C. E. Jakobsche and S. J. Miller, J. Am. Chem. Soc., 2007, 129, 8710.

38 P. A. Lichtor and S. J. Miller, Nat. Chem., 2012, 4, 990.

39 P. A. Lichtor and S. J. Miller, J. Am. Chem. Soc., 2014, 136, 5301.

40 N. C. Abascal, P. A. Lichtor, M. W. Giuliano and S. J. Miller, Chem. Sci., 2014, 5, 4504.

41 D. K. Romney and S. J. Miller, Org. Lett., 2012, 14, 1138.

42 O. Cussó, I. Garcia-Bosch, X. Ribas, J. Lloret-Fillol and M. Costas, J. Am. Chem. Soc., 2013, 135, 14871.

43 T. S. Haque, J. C. Little and S. H. Gellman, J. Am. Chem. Soc., 1996, 118, 6975.

44 (a) C. M. Wilmot and J. M. Thornton, J. Mol. Biol., 1988, 203, 221; (b) A. J. Metrano, N. C. Abascal, B. Q. Mercado, E. K. Paulson, A. E. Hurtley and S. J. Miller, J. Am. Chem. Soc., 2017, 139, 492.

45 O. Cussó, X. Ribas, J. Lloret-Fillol and M. Costas, Angew. Chem., Int. Ed., 2015, 54, 2729.

46 O. Cussó, M. Cianfanelli, X. Ribas, K. R. J. M. Gebbink and M. Costas, J. Am. Chem. Soc., 2016, 138, 2732.

47 X. Wang, C. Miao, S. Wang, C. Xia and W. Sun, ChemCatChem, 2013, 5, 2489.

48 R. Mas-Balleste and L. Que Jr, J. Am. Chem. Soc., 2007, 129, 15964.

49 A. M. Zima, O. Y. Lyakin, R. V. Ottenbacher, K. P. Bryliakov and E. P. Talsi, ACS Catal., 2017, 7, 60.

50 L. Gomez, I. Garcia-Bosch, A. Company, J. Benet-Buchholz, A. Polo, X. Sala, X. Ribas and M. Costas, Angew. Chem., Int. Ed., 2009, 48, 5720.

51 (a) E. L. Hegg and L. Que Jr, Eur. J. Biochem., 1997, 250, 625; (b) E. G. Kovaleva and J. D. Lipscomb, Nat. Chem. Biol., 2008, 4, 186; (c) S. M. Barry and G. L. Challis, ACS Catal., 2013, 3, 2362.

52 Good ee's in the asymmetric epoxidation of $\alpha$-alkystyrenes with no substitutions at the $o$-position are limited to chloroperoxidase (up to $89 \%$ ee), A. F. Dexter, F. J. Lakner, 
R. A. Campbell and L. P. Hager, J. Am. Chem. Soc., 1995, 117, 6412, Shi's organocatalysts (up to $88 \%$ ee), B. Wang, O. A. Wong, M.-X. Zhao and Y. Shi, J. Org. Chem, 2008, 73, 9539, and O. A. Wong, B. Wang, M.-X. Zhao and Y. Shi, J.
Org. Chem, 2009, 74, 6335, and the combination of $\left(S, S^{\prime}\right)^{\mathbf{M e 2 N}} \mathbf{1 F e}$ with Npha-Ileu-OH (ref. 45).

53 V. Capriati, S. Florio, F. M. Perna and A. Salomone, Chem.Eur. J., 2010, 16, 9778. 